\title{
PENGARUH BAURAN PEMASARAN TERHADAP PENJUALAN PADA PT. NESTLE INDOFOOD CITARASA INDONESIA DI MAKASSAR
}

\author{
Nuraini Rasyid ${ }^{1}$, Rais Dera Pua Rawi ${ }^{2}$ \\ Dosen Stie Wira Bhakti Makassar \\ Dosen Fakultas Ekonomi Universitas Muhammadiyah Sorong \\ Hj.nurainirr@gmail.com
}

\begin{abstract}
Abstrak
Penelitian ini bertujuan untuk mengetahui pengaruh bauran pemasaran yang terdiri dari harga, produk, distribusi dan promosi terhadap penjualan sambel Indofood pada PT. Nestle Citarasa Indonesia di Makassar.Sedangkan jenis penelitian adalah penelitian kuantitatif dengan menggunakan metode analisis data, 1) Analisis deskriptif digunakan untuk menjelaskan pengaruh bauran pemasaran yang terdiri dari harga, produk, distribusi dan promosi terhadap penjualan sambel Indofood. 2) Analisis regresi berganda mengukur keterkaitan unsur-unsur bauran pemasaran terhadap peningkatan penjualan sambel Indofood, persamaan yaitu : $Y=b_{0}+b_{1} X_{1}+b_{2} X_{2}+b_{3} X_{3}+e$. Hasil penelitian menunjukkan bahwa koefisien regresi memperlihatkan hasil koefisien konstanta (variabel Penjualan) adalah sebesar 3,173 dengan $\mathrm{T}_{\text {hitung }}$ sebesar 3,574 dan nilai signifikansi sebesar 0,037, variabel Harga (X1) adalah sebesar 0,401 dengan Thitung sebesar 5,547 dan nilai signifikan sebesar 0,012, variabel Biaya Promosi (X2) adalah sebesar 0,751 dengan $\mathrm{T}_{\text {hitung }}$ sebesar 12,498 dan nilai signifikan sebesar 0,001 dan untuk variabel Biaya Distribusi sebesar -0,098 dengan $\mathrm{T}_{\text {hitung }}$ sebesar -7,955 dan nilai signifikan sebesar 0,004 . Nilai Ttabel untuk uji ini adalah sebesar 1,943 yang diperoleh dengan alpha 5\% dan df sebesar 6 (n-1). Jika kita bandingkan nilai $\mathrm{T}_{\text {hitung }}$ koefisien konstanta dengan $\mathrm{T}_{\text {tabel }}$, terlihat bahwa nilai $T_{\text {hitung }}$ lebih besar dari pada $T_{\text {tabel }}$, dan nilai signifikan yang lebih kecil dari pada alpha 5\%, maka kesimpulan yang bisa diambil adalah menolak Ho yang berarti signifikan secara statistik.
\end{abstract}

Kata kunci ; Bauran pemasaran, penjualan, Nestle Citarasa

\section{Pendahuluan}

Pemasaran merupakan kegiatan penting dari perusahaan yang menghasilkan produk untuk dijual, dengan tujuan untuk memperoleh keuntungan. Dengan keuntungan tersebut diharapkan perusahaan bersangkutan bukan saja dapat mempertahankan kelanjutan usahanya, tetapi juga dapat dikembangkan lebih besar. Berkembangnya sistem pemasaran dalam dunia perdagangan sekarang ini adalah di samping disebabkan oleh semakin menjamurnya media yang memberikan kemudahan dalam berbelanja juga akibat kondisi dari konsumen itu sendiri yang selalu berlomba dengan waktu dan senantiasa menghindari halhal yang dianggap mengurangi keyakinan mereka dalam berbelanja. Menurut Wangsi \& Rawi (2018), menjelaskan bahwa Tingginya permintaan dan kemajuan teknologi menyebabkan terjadinya peningkatan terhadap barang yang dikonsumsi oleh konsumen. Dan seiring berkembangnya zaman pun menjadikan barang yang dikonsumsi 
ikut turut meningkat persediaannya. Para konsumen yang dihadapkan oleh banyaknya pilihan dari berbagai jenis dan macam barang adalah akibat dari meningkatnya jumlah dan kualitas barang-barang yang dikonsumsi secara terus menerus. Upaya menciptakan tingkat kepuasan dan menguasai pangsa pasar, bukanlah persoalan mudah, karena perusahaan harus mampu mengkombinasikan unsurunsur pemasaran yang biasa disebut dengan bauran pemasaran (marketing mix) dengan faktor-faktor lainnya seperti pelayanan. Dengan menerapkan bauran pemasaran, perusahaan akan memperoleh keuntungan secara optimal, karena bauran pemasaran merupakan inti dari konsep pemasaran yang meliputi: produk, harga, distribusi, dan promosi. Ke empat unsur tersebut dalam kegiatan pemasaran menduduki posisi yang setara, sehingga ke empat unsur tersebut harus mendapatkan perhalian yang sama.

PT. Nestle Indofood Citarasa Indonesia merupakan salah satu perusahaan yang inovatif dan selalu mampu menghadirkan berbagai

\section{Tujuan Penelitian}

\section{Tujuan penelitian ini adalah:}

1. Untuk mengetahui pengaruh bauran pemasaran yang terdiri dari harga, produk, distribusi dan promosi terhadap penjualan sambel Indofood pada PT. Nestle Citarasa Indonesia di Makassar.

\section{Metodologi Penelitian}

macam produk yang tepat guna memuaskan kebutuhan para konsumennya. Produk-produk PT. Nestle Indofood Citarasa Indonesia dikenal oleh masyarakat sebagai produk yang memiliki terobosan yang paling inovatif, salah satu produknya yang juga menjadi fokus dalam penelitian ini yaitu sambel Indofood yang memiliki kelebihan pada citarasanya yang tidak tertandingi dan harganya yang sangat terjangkau dibandingkan dengan produk sejenis yang dihasilkan oleh para Kompetitor.Karena tujuan perusahaan adalah memberi hasil kepuasan terhadap konsumen baik pemakai industri maupun konsumen akhir. Untuk lebih mencurah masalah hasil produksi, maka penulis memilih salah satu perusahaan sebagai objek penelitian yang daerah pemasarannya adalah Makassar dan sekitarnya. Sejalan dengan uraian tersebut, maka penelitian ini dilakukan dengan judul, "Pengaruh Bauran Pemasaran Terhadap penjualan pada PT. Nestle Indofood Citarasa Indonesia di Makassar.

\section{Jenis dan Sumber Data}

1. Jenis data yang digunakan dalam penelitian ini adalah:

a. Data kualitatif, yaitu data yang diperoleh dari perusahaan dalam bentuk informasi baik secara lisan maupun secara tertulis.

b. Data kuantitatif, yaitu data yang berhubungan dengan angka - angka seperti volume penjualan perusahaan. 
2. Sumber data yang digunakan dalam penelitian ini adalah :

a. Data primer, yaitu data yang diperoleh secara langsung dari perusahaan berdasarkan hasil observasi dan wawancara dengan pimpinan dan karyawan.

b. Data sekunder, yaitu data yang diperoleh dari dokumen perusahaan, berupa laporan tertulis yang dibuat secara berkala.

\section{Metode Analisis}

Adapun metode analisis yang digunakan dalam penelitian adalah sebagai berikut :

1. Analisis deskriptif digunakan untuk menjelaskan pengaruh bauran pemasaran yang terdiri dari harga, produk, distribusi dan promosi terhadap penjualan sambel Indofood pada PT. Nestle Citarasa Indonesia di Makassar.

2. Analisis regresi berganda digunakan untuk mengetahui pola dan mengukur keterkaitan unsurunsur bauran pemasaran terhadap peningkatan penjualan sambel Indofood, dengan menggunakan persamaan sebagaiiklan yang

\section{HASIL PENELITIAN DAN PEMBAHASAN}

\section{Analisis Bauran Pemasaran}

Salah satu unsur dalam strategi pemasaran atau strategi bauran pemasaran atau disebut Marketing Mix. Dimana Marketing Mix adalah kombinasi dari 4 variabel atau dikemukakan oleh Muhammad Arif Tiro (2004: 108) yaitu :

$\mathrm{Y}=\mathrm{b}_{0}+\mathrm{b}_{1} \mathrm{X}_{1}+\mathrm{b}_{2} \mathrm{X}_{2}+\mathrm{b}_{3} \mathrm{X}_{3}+\mathrm{e}$ di iklan -. $\mathrm{Y}=$ Volume penjualan bo, bl, b2, b3, = Konstanta (merupakan koefisien regresi)

$\mathrm{X}$, = Harga

$\mathrm{X} 2$ = Biaya promosi

X3 = Biaya saluran distribusi

$\mathrm{e}=$ Standar error

Persamaan di atas diselesaikan melalui komputer dengan menggunakan Program SPSS versi 20,5. Hasil tersebut akan diperoleh nilai-nilai keefesien regresi $\left(b_{1}\right.$, $b_{2}$, dan $b_{3}$, Koefisien korelasi $(\mathrm{R})$, koefisien determinasi $\left(\mathrm{R}^{2}\right)$, nilai $\mathrm{F}_{\text {hitumg }}$ dan $\mathrm{T}_{\text {hitung. Pengujian hipotesis }}$ (Uji F) adalah suatu analisis yang digunakan untuk mengetahui apakah seluruh variabel bebas secara bersamasama mempunyai pengaruh yang bermakna terhadap variabel terikat. Pengujian dilakukan dengan membandingkan nilai $\mathrm{F}_{\text {hitung }}$ dengan $\mathrm{F}$ tabel pada derajat kesalahan $5 \%$ $(\mathrm{d}=0,05)$. Apabila nilai $\mathrm{F}_{\text {hitung }}>$ dari nilai $F$ tabel maka berarti variabel bebasnya secara serempak memberikan pengaruh yang bermakna terhadap variabel terikat.

kegiatan yang merupakan inti dari sistem pemasaran perusahaan yaitu sebagai berikut:

1. Produk (Product)

2. Harga (Price)

3. Promosi (Promotion)

4. Distribusi (Place)

Keempat unsur-unsur tersebut sating berhubungan. Oleh karena itu, iklanjer harus menilai atau 
memilih kombinasi terbaik yang dapat disesuaikan dengan lingkungan bisnis. Berikut ini akan diuraikan unsurunsur dari Marketing Mix tersebut sebagaiiklan dijalankan oleh PT. Nestle Indofood Citarasa Indonesia di Makassar.

1. Analisis Produk

Sebagaiiklan diketahui bahwa produk adalah merupakan hasil dari suatu proses produksi yang dilakukan oleh suatu perusahaan yang selanjutnya akan dipasarkan kepada konsumen. Suatu produk yang telah diproduksi oleh suatu perusahaan senantiasa diusahakan agar produk tersebut dapat memenuhi kebutuhan dan kepuasan konsumen, selain itu" perusahaan harus pula senantiasa menjaga kualitas dari produk yang dihasilkan agar konsumen dapat dipertahankan dan ditingkatkan.

Strategi yang dilakukan PT. Nestle Indofood Citarasa Indonesia agar supaya hasil kemasan produk saos sambal indofood dapat diterima diseluruh lapisan masyarakat adalah dengan mengemas saos sambal Indofood dengan ukuran botol kaca 340 ML dan beberapa macam rasa sebagai berikut:
a. Sambal pedas
b. Sambal extra pedas
c. Sambal pedas iklanis
d. Sambal lampung
e. Sambal Seafood
f. Sambal Bangkok asam iklanis

\section{Analisis Harga}

Besar kecilnya perusahaan sangat erat hubungannya dengan penetapan harga disamping variabelvariabel lainnya, volume penjualan suatu barang sering disebabkan oleh besarnya harga yang ditawarkan oleh pihak produsen terlalu tinggi sedangkan harga yang diminta oleh konsumen lebih rendah. Dalam penetapan harga perusahaan harus memperhatikan kemampuan dari produk tersebut dalam memberi iklanfaat yang besar bagi konsumen bila membeli atau memiliki barang tersebut. Karena apabila barang yang ditetapkan terlalu besar dibanding iklanfaat yang diberikan oleh produk. Walaupun kemampuan konsumen ada, maka produk tersebut tidak akan laku.

Berdasarkan hasil penelitian, harga produk di pasar akan terbentuk oleh keadaan atau kondisi, artinya jika PT. Nestle Indofood Citarasa Indonesia berusaha menurunkan harga dengan harapan penjualan perusahaan akan meningkat, maka konsekuensinya yang mungkin ditemui hanyalah kerugian mengingat terdapatnya perusahaan pesaing, sebaliknya jika perusahaan menaikkan harga berarti kemungkinan terjualnya produk di pasaran sangat kecil. Dalam hubungan ini maka penentuan harga jual di pasar memerlukan telaah lebih lanjut guna menghindari adanya kerugian-kerugian. Ini penting artinya mengingat terdapatnya sejumlah perusahaan pesaing yang mempunyai jangkauan konsumen dalam pemasarannya. Oleh karena itu, maka penentuan harga jual pada PT. Nestle Indofood Citarasa Indonesia didasarkan pada tingkat 


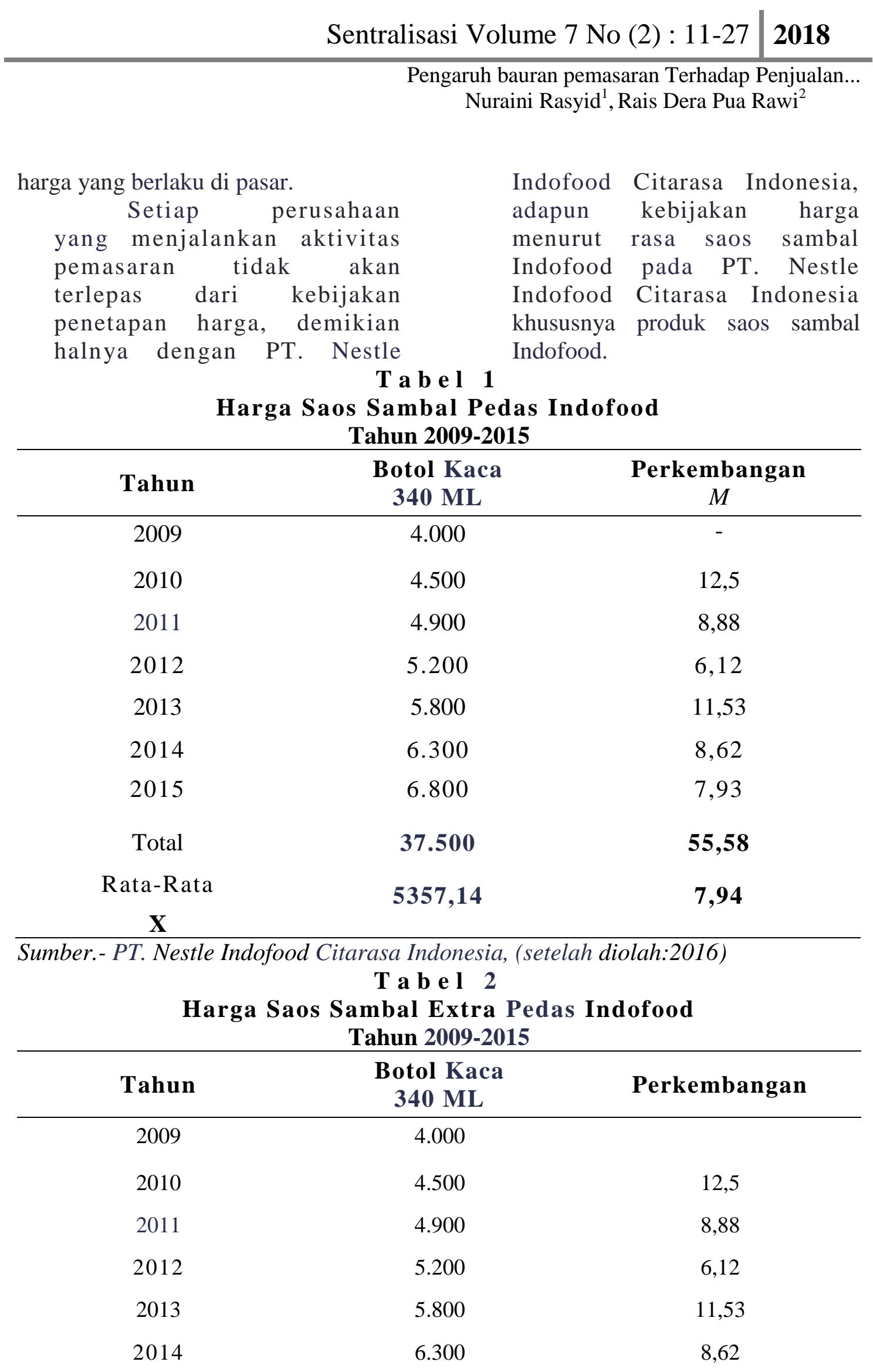




\begin{tabular}{|c|c|c|c|}
\hline & \multicolumn{2}{|c|}{ Sentralisasi Volume 7 No (2) : 11-27 } & 2018 \\
\hline & \multicolumn{3}{|c|}{$\begin{array}{l}\text { Pengaruh bauran pemasaran Terhadap Penjualan... } \\
\text { Nuraini Rasyid }{ }^{1}, \text { Rais Dera Pua Rawi }{ }^{2}\end{array}$} \\
\hline 2015 & 6.800 & 7,93 & \\
\hline Total & 37.500 & 55,58 & \\
\hline$\frac{\text { Rata-Rata }}{\mathbf{X}}$ & 5357,14 & 7,94 & \\
\hline \multicolumn{4}{|c|}{$\begin{array}{c}\text { Sumber. - PT. Nestle Indofood Citarasa Indonesia, (setelah diolah:2008) } \\
\text { T a b e } \mathbf{~} \mathbf{3} \\
\text { Harga Saos Sambal Pedas Iklanis Indofood } \\
\text { Tahun 2001-2007 }\end{array}$} \\
\hline Tahun & $\begin{array}{l}\text { Botol Kaca } \\
340 \mathrm{ML}\end{array}$ & Perkembai & ngan \\
\hline 2009 & 4.000 & & \\
\hline 2010 & 4.500 & 12,5 & \\
\hline 2011 & 4.900 & 8,88 & \\
\hline 2012 & 5.200 & 6,12 & \\
\hline 2013 & 5.800 & 11,53 & \\
\hline 2014 & 6.300 & 8,62 & \\
\hline 2015 & 6.800 & 7,93 & \\
\hline Total & 37.500 & 55,58 & \\
\hline$\frac{\text { Rata-Rata }}{X}$ & 5357,14 & 7,94 & \\
\hline
\end{tabular}

Sumber PT. Nestle Indofood Citarasa Indonesia, (setelah diolah:2016)

Tabel 4

Harga Saos Sambal Lampung Indofood

Tahun 2009-2015

\begin{tabular}{|c|c|c|}
\hline Tahun & $\begin{array}{c}\text { Botol Kaca } \\
340 \mathrm{ML}\end{array}$ & Perkembangan \\
\hline 2009 & 4.000 & - \\
\hline 2010 & 4.500 & 12,5 \\
\hline 2011 & 4.900 & 8,88 \\
\hline 2012 & 5.200 & 6,12 \\
\hline 2013 & 5.800 & 11,53 \\
\hline 2014 & 6.300 & 8,62 \\
\hline 2015 & 6.800 & 7,93 \\
\hline
\end{tabular}




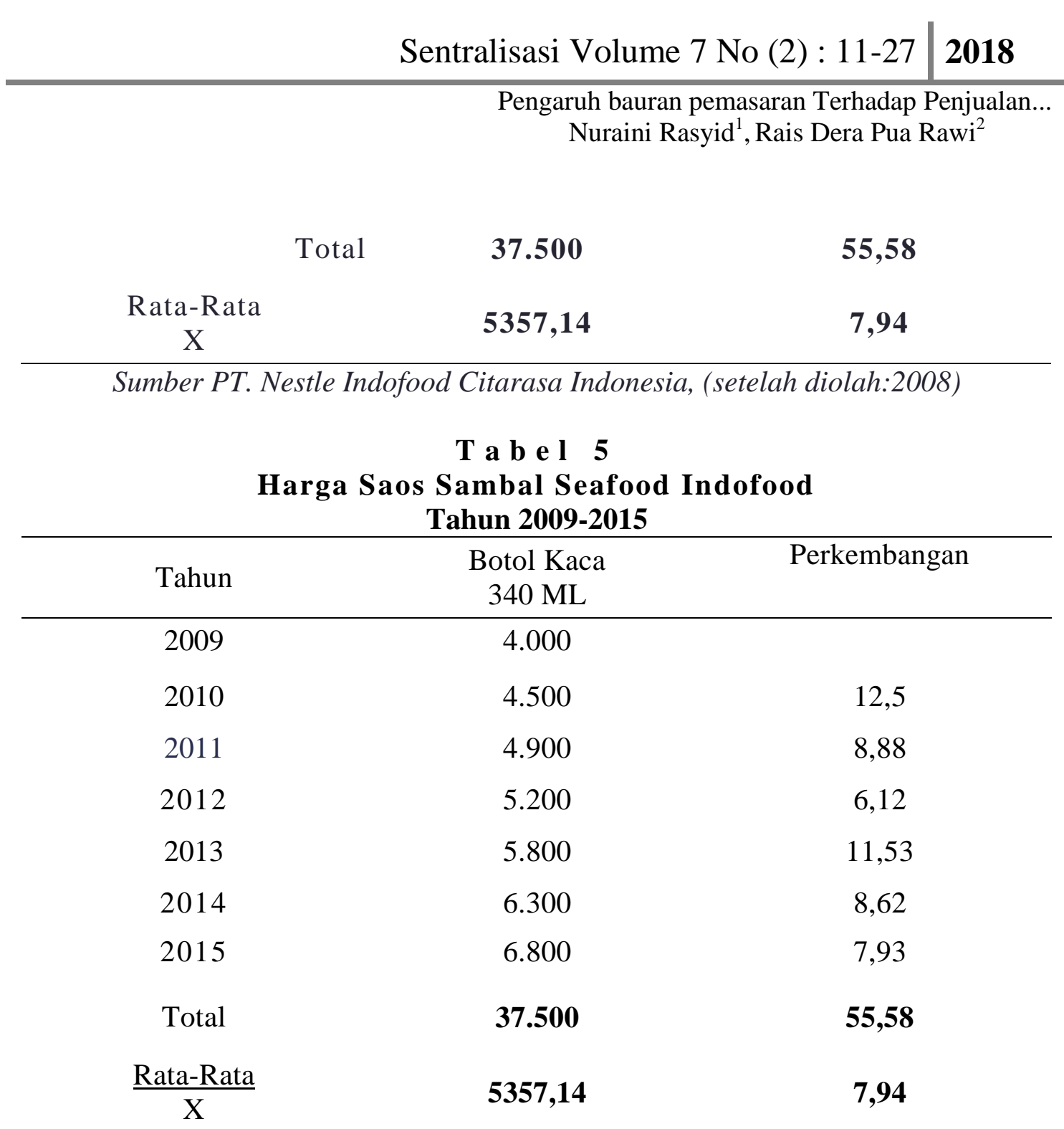

Sumber: PT. Nestle Indofood Citarasa Indonesia, (setelah diolah:2016)

Perkembangan harga saos sambal Indofood dimulai dari tabel 1 sampai tabel ke 5 sama. Hal ini dikarenakan harga saos sambal Indofood dari ke 5 macam rasa tersebut sama,dimulai dari saos sambal pedas Indofood, saos sambal extra pedas Indofood, saos sambal pedas iklanis Indofood, saos sambal lampung Indofood, dan saos sambal seafood Indofood.Harga saos sambal Indofood tiap tahunnya meningkat, hal ini didasarkan pada tingkat harga yang berlaku dipasaran. Pada tahun 2011 -
2012 harga saos sambal Indofood mengalami kenaikan hingga $8,88 \%$ di tahun 2011 dan 6,12\% ditahun 2012. Selanjutnya pada tahun 2013-2014 persentase harga saos sambal Indofood mengalami kenaikan harga menjadi $11,35 \%$ ditahun 2012, di tahun 2013 sebesar $8,62 \%$ dan tahun 2014 sebesar 7,93\%. Dengan meningkatnya harga saos sambal Indofood setiap tahunnya maka perusahaan mengharapkan penjualan juga akan meningkat. 


\begin{tabular}{|c|c|c|c|}
\hline & \multicolumn{2}{|c|}{ Sentralisasi Volume 7 No (2) : 11-27 } & 2018 \\
\hline \multirow{2}{*}{\multicolumn{4}{|c|}{$\begin{array}{c}\text { Pengaruh bauran pemasaran Terhadap Penjualan } \\
\text { Nuraini Rasyid }{ }^{1} \text {, Rais Dera Pua Rawi }{ }^{2}\end{array}$}} \\
\hline & & & \\
\hline Tahun & $\begin{array}{l}\text { Botol Kaca } \\
340 \mathrm{ML}\end{array}$ & \multicolumn{2}{|c|}{$\begin{array}{c}\text { Perkembangan } \\
(\%)\end{array}$} \\
\hline 2009 & 4.500 & \multicolumn{2}{|l|}{-} \\
\hline 2010 & 4.900 & \multicolumn{2}{|l|}{8,88} \\
\hline 2011 & 5.100 & \multicolumn{2}{|l|}{4,08} \\
\hline 2012 & 5.600 & \multicolumn{2}{|l|}{9,80} \\
\hline 2013 & 6.900 & \multicolumn{2}{|l|}{23,21} \\
\hline 2014 & 7.400 & \multicolumn{2}{|l|}{7,24} \\
\hline 2015 & 8.250 & \multicolumn{2}{|l|}{11,48} \\
\hline Total & 42.650 & \multicolumn{2}{|l|}{64,69} \\
\hline$\frac{\text { Rata-Rata }}{\mathrm{X}}$ & 6092,85 & \multicolumn{2}{|l|}{9,24} \\
\hline
\end{tabular}

Sumber. PT. Nestle Indofood Citarasa Indonesia, (setelah diolah.-2016)

Khusus untuk harga produk saos sambal Bangkok asam iklanis Indofood berbeda dengan harga saos sambal lainnya karena produk ini memiliki rasa khas sambal Thailand dengan rasa iklanis yang lebih dominan.Perkembangan harga saos sambal Bangkok asam iklanis terus meningkat setiap tahunnya. Pada tahun 2011-2012 harga saos sambal Indofood mengalami kenaikan hingga 4,08\% di tahun 2011 dan 9,80\% ditahun 2012 . Selanjutnya pada tahun 2013 -
2015 persentase harga saos sambal Indofood mengalami kenaikan harga menjadi $23,21 \%$ ditahun 2013, di tahun 2014 sebesar 7,24\% dan tahun 2015 sebesar $11,48 \%$. Harga saos sambal Indofood tiap tahunnya meningkat, hal ini didasarkan pada tingkat harga yang berlaku dipasaran. Dengan meningkatnya harga saos sambal Indofood setiap tahunnya maka perusahaan mengharapkan penjualan juga akan meningkat. 
T a b e 17

Kompilasi Perkembangan Harga Rata-Rata Saos Sambal Indofood Tahun 2009-2015

\begin{tabular}{lcc}
\hline \multicolumn{1}{c}{ Produk } & Harga Rata-Rata & $\begin{array}{c}\text { Rata-Rata } \\
\text { Perkembangan }(\%)\end{array}$ \\
\hline Saos Sambal Pedas & 5357,14 & 7,94 \\
Saos Sambal Extra Pedas & 5357,14 & 7,94 \\
Saos Sambal Pedas Iklanis & 5357,14 & 7,94 \\
Saos Sambal Lampung & 5357,14 & 7,94 \\
Saos Sambal Seafood & 5357,11 & 7,94 \\
Saos Sambal Bangkok Asam Iklanis & 6092,85 & 9,24
\end{tabular}

Surnber.- PT. Nestle Indofood Citarasa Indonesia,(setelah diolah:2016)

Kompilasi perkembangan
harga rata-rata saos sambal
indofood dari keenam macam rasa
hanya saos sambal rasa Bangkok asam
iklanis yang memiliki harga rata-rata
dan rata-rata perkembangan yang
berbeda yaitu 6092,85 untuk harga
rata-ratanya dan $9,24 \%$ untuk rata-rata

3. Analisis Promosi

Untuk dapat menjalin kerjasama dalam melakukan kegiatan pemasaran dengan pihak eksternal perusahaan, usaha yang dapat dilakukan perusahaan - perusahaan yaitu dengan melakukan komunikasi dengan calon pengecer atau pembeli.

$$
\text { Promosi merupakan }
$$

bagian dari marketing mix yang berfungsi sebagai salah satu alat komunikasi antara perusahaan dengan pasar yang bertujuan untuk mengetahui keinginan konsumen. Dengan adanya komunikasi yang seperti ini maka perkembangannya. Sedangkan kelima produk saos sambal Indofood lainnya memiliki harga ratarata dan rata-rata perkembangan yang sama.Yaitu 5357,14 untuk harga rata-rata dan $7,94 \%$ untuk ratarata perkembangannya.

PT. Nestle Indofood Citarasa Indonesia dapat mengetahui jenis dan harga dari produk yang diinginkan konsumen. Dengan promosi yang diterapkan ini diharapkan volume penjualan saos sambal indofood semakin meningkat.Berbagai kebijakan promosi yang selama ini dilakukan oleh PT. Nestle Indofood Citarasa Indonesia dalam memasarkan produk diantaranya dalam bentuk :

a. Periklanan

Periklanan adalah cara mempromosikan produk saos sambal indofood melalui media cetak, radio swasta, maupun papan 
Iklan, poster, umbul - umbul, stiker dan brosur.

b. Penjulalan Tatap Muka

Penjualan tatap muka yang selama ini dilakukan oleh PT. Nestle Indofood Citarasa Indonesia adalah merupakan bentuk promosi yang efektif dengan menempatkan beberapa tenaga sales iklan pada beberapa supermarket. Kegiatan ini dilakukan dengan bertujuan untuk memberi pelayanan yang memuaskan bagi konsumen balk yang hanya membutuhkan informasi tentang produk saos sambal indofood maupun konsumen yang tertarik dengan produk tersebut.

c. Promosi Penjulan

Promosi penjualan yang biasanya dilakukan adalah dengan berpartisipasi pada berbagai pameran-pameran yang diselenggarakan oleh pemerintah maupun swasta. Disamping itu juga dilakukan melalui pemberian hadiah langsung (bonus) kepada pembeli dan undian-undian lainnya yang lebih menarik.

Secara umum, dalam memasarkan produknya PT. Nestle Indofood Citarasa Indonesia menerapkan strategi promosi sebagai berikut:
a) Memberikan brosur pada setiap calon user
b) Memasangkan panfel- panfel produk saos sambal indofood pada setiap pengecer
c) Memberikan special price untuk pembelian produk dalam partai besar.
d) Memasangkan Iklan di media massa

Adapun besarnya biaya promosi yang dikeluarkan oleh PT. Nestle Indofood Citarasa Indonesia selama tahun 2009 - 2015 adalah sebagai berikut:

\section{T a b e l . 8}

Biaya promosi yang dikeluarkan PT. Nestle Indofood Citarasa Indonesia tahun 2009 - 2015

\begin{tabular}{ccc}
\hline Tahun & Biaya Promosi (Rp) & $\begin{array}{c}\text { Perkembangan } \\
(\%)\end{array}$ \\
\hline 2009 & 368.000 .000 & - \\
2010 & 393.000 .000 & 6,79 \\
2011 & 410.000 .000 & 4,32 \\
2012 & 420.000 .000 & 2,43 \\
2013 & 455.000 .000 & 8,33 \\
2014 & 450.000 .000 & $(1,09)$ \\
2015 & 510.000 .000 & 13,33 \\
& 3.006 .000 .000 & 34,11
\end{tabular}


$\underline{\text { Rata-rata }}$

$429.428 .571,4$

4,87

Sumber. PT. Nestle Indofood Citarasa Indonesia, (Setelah diolah: 2018)

Besarnya biaya promosi yang dikeluarkan oleh PT. Nestle Indofood Citarasa Indonesia selama tahun $2009 \quad-\quad 2015$ berfluktuasi. Fluktuasi besarnya biaya promosi tersebut disebabkan karena adanya perekonomian yang tidak stabil dan cenderung mengalami penurunan yang sangat drastis sehingga sulit untuk melalukan promosi secara besar-besaran. Pada tahun 2011-2012 besarnya biaya promosi mengalami penurunan sampai dengan $4,32 \%$ ditahun 2011 dan $2,43 \%$ ditahun 2012. Selanjutnya tahun 2013 sampai dengan 2014 persentase biaya promosi terus meningkat menjadi sampai dengan 8,33\% ditahun 2013, tahun 2014 sebesar $(1,09) \%$ dan tahun 2015 sebesar $13,33 \%$. Dengan meningkatnya biaya promosi yang dikeluarkan oleh perusahaan mengakibatkan volume penjualan saos sambal indofood pada tahun tersebut mengalami peningkatan.

\section{Analisis Distribusi}

Untuk lebih jelas dan memahami saluran distribusi dari PT. Nestle Indofood Citarasa Indonesia dapat

Untuk memperlancar arus barang dan jasa dari produsen ke konsumen maka salah satu strategi penting yang dilakukan adalah memilih saluran distribusi bagi perusahaan merupakan hak mutlak untuk diperhatikan agar permintaan dari konsumen dapat dilayani dengan cepat.Strategi distribusi merupakan strategi yang berkaitan erat dengan upaya perusahaan untuk mendistribusikan atau menyalurkan produk kepada konsumen, oleh karena itu peranan saluran distribusi atau saluran pemasaran sebagai perantara produk ke konsumen sangatlah penting.Di dalam usaha untuk mencapai tujuan dan sasaran perusahaan maka PT. Nestle Indofood Citarasa Indonesia di dalam memasarkan produknya menggunakan saluran distribusi langsung di iklan dari perusahaan langsung ke konsumen dan juga saluran distribusi tidak langsung di iklan dari perusahaan ke pengecer baru ke konsumen.

dilihat gambar di bawah ini :

Distribusi langsung

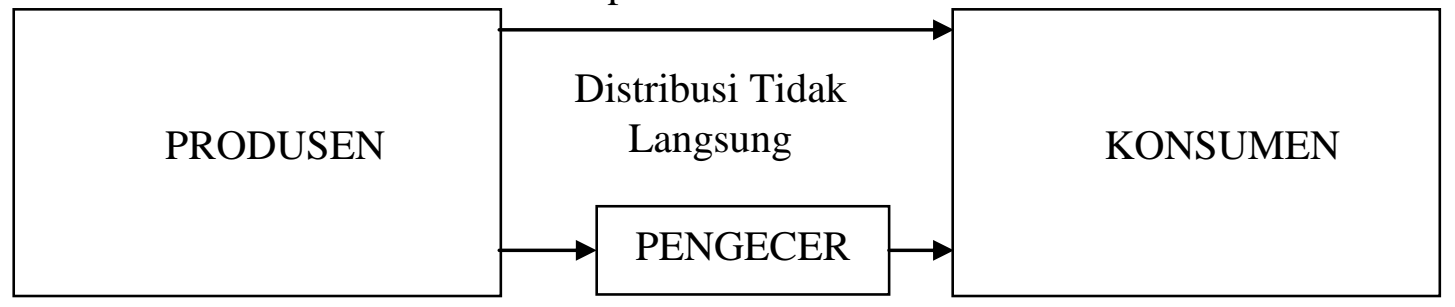


Pengaruh bauran pemasaran Terhadap Penjualan... Nuraini Rasyid ${ }^{1}$, Rais Dera Pua Rawi ${ }^{2}$

Sumber: PT. Nestle Indofood Citarasa Indonesia, 2016

Analisis Perkembangan Hasil Penjualan

Dalam mengembangkan usaha pemasaran produk-produk pada PT. Nestle Indofood Citarasa Indonesia di Makassar khususnya sambel Indofood, biasanya perusahaan mengadakan analisis terhadap penjualan, dilakukan untuk mengetahui sejauh iklan kemampuan mengembangkan perusahaan manajemen penjualannya dalam menjual produknya. Apa sudah memenuhi target dan yang lebih penting lagi apakah penjualan yang dilakukan sudah mendapat respon dari pihak luar negeri. Berikut ini disajikan perkembangan pejualannya yang dicapai PT. Nestle Indofood Citarasa Indonesia di Makassar pada tahun 2009-2015 dapat dilihat pada tabel berikut ini:

\section{T a b e l 9}

Perkembangan Penjualan Saos Sambal Indofood Pada PT. Nestle Indofood Citarasa Indonesia

Tahun 2009-2015

\begin{tabular}{ccc}
\hline Tahun & Penjualan $(\mathrm{Rp})$ & Perkembangan $(\%)$ \\
\hline 2009 & 18.500 .000 .000 & - \\
2010 & 19.000 .000 .000 & 2,70 \\
2011 & 21.500 .000 .000 & 13,15 \\
2012 & 21.400 .000 .000 & $(0,46)$ \\
2013 & 22.000 .000 .000 & 2,80 \\
2014 & 23.300 .000 .000 & 5,90 \\
2015 & 25.800 .000 .000 & 10,72
\end{tabular}

Sumber: PT. Nestle Indofood Citarasa Indonesia, 2016

\section{Pengaruh Bauran Pemasaran Terhadap Penjualan}

Untuk mengukur pengaruh bauran pemasaran terhadap penjualan, proyeksi penjualan tahun berikutnya, harus berdasar pada tahun yang telah diteliti. Jika dilihat dari tabel yang telah diuraikan sebelumnya ternyata semua komponen yang terkait pada PT. Nestle Indofood Citarasa Indonesia di Makassar mengalami peningkatan secara keseluruhan. Untuk membuktikan pengaruh bauran pemasaran pada PT. Nestle Indofood Citarasa Indonesia di Makassar, maka akan diuji dengan menggunakan regresi berganda dengan bantuan komputer (Program SPSS). Untuk mempermudah data yang akan diolah, maka berikut ini akan ditampilkan data tersebut, pada tabel 10 berikut ini : 
Tabel 10

Hasil Perhitungan Regresi Berganda Dengan Program SPSS Versi

11,5

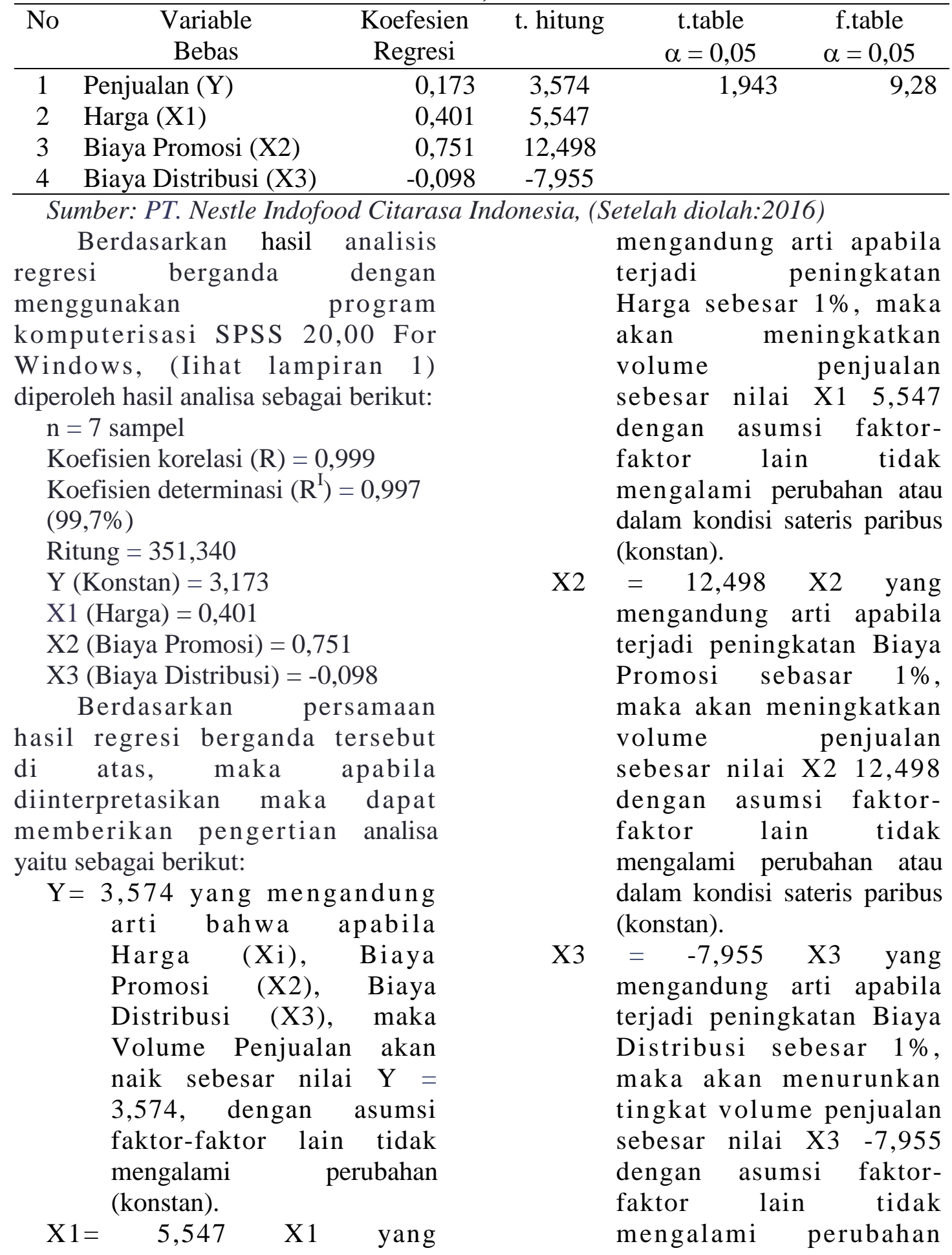



Nuraini Rasyid ${ }^{1}$, Rais Dera Pua Rawi ${ }^{2}$

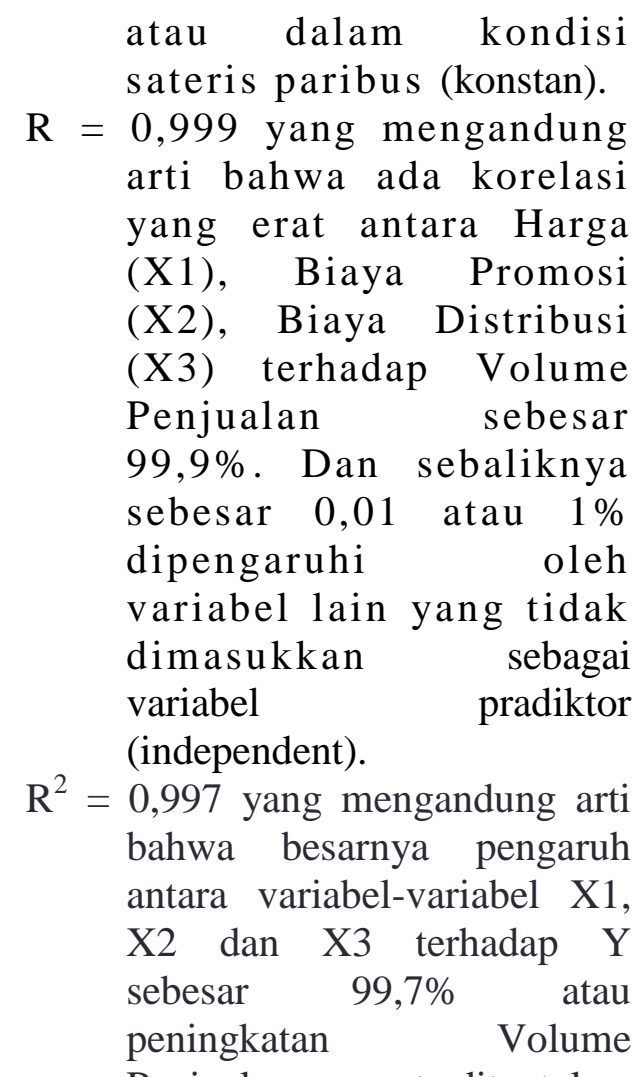
Penjualan sangat ditentukan oleh Harga Jual, Biaya Promosi dan Biaya Distribusi dan variabel lain yang ticlak dimasukkan sebagai variabel lain yang tidak dimasukkan sebagai variabel pradiktor (independent) yaitu sebesar $1 \%$.

Dari data di atas didapatkan nilai $F$ hitung 351,340 yang dapat digunakan untuk melakukan uji hipotesis dalam memprecliksi kontribusi variabel-variabel independent $\left(\mathrm{X}_{1}\right.$, $\mathrm{X}_{2}$ dan $\mathrm{X}_{3}$ ) terhadap variabel dependent

(Y)

Berdasarkan pada penjelasan tersebut di atas, maka terjawablah masalah pokok maupun hipotesis dari ketiga variabel yang penulis telah ajukan pada pembahasan terdahulu, diperoleh dari tabel anova nilai $F_{\text {hitung }}$ Sebesar 351,340 dengan nilai signifikansi sebesar 0,000 atau lebih kecil dari alpha 0,05 . Sedangkan nilai Ftabel 9,28, maka kondisi tersebut terlihat bahwa nilai Fhitung lebih bestir dari pada Ftabei dan nilai signifikansi lebih kecil dari pada alpha, maka kesimpulan yang bisa diambil adalah menolak Ho yang berarti koefisien Determinasi adalah signifikan secara statistik.

Berdasarkan hasil perhitungan koefisien regresi memperlihatkan hasil koefisien konstanta (variabel Penjualan) adalah sebesar 3,173 dengan $\mathrm{T}_{\text {hitung }}$ sebesar 3,574 dan nilai signifikansi sebesar 0,037, variabel Harga (X1) adalah sebesar 0,401 dengan Thitung sebesar 5,547 dan nilai signifikan sebesar 0,012, variabel Biaya Promosi (X2) adalah sebesar 0,751 dengan $\mathrm{T}_{\text {hitung }}$ sebesar 12,498 dan nilai signifikan sebesar 0,001 dan untuk variabel Biaya Distribusi sebesar 0,098 dengan $\mathrm{T}_{\text {hitung }}$ sebesar $-7,955$ dan nilai signifikan sebesar 0,004 . Nilai Ttabel untuk uji ini adalah sebesar 1,943 yang diperoleh dengan alpha $5 \%$ dan df sebesar 6 (n-1). Jika kita bandingkan nilai $\mathrm{T}_{\text {hitung }}$ koefisien konstanta dengan $\mathrm{T}_{\text {tabel }}$, terlihat bahwa nilai $\mathrm{T}_{\text {hitung }}$ lebih besar dari pada $\mathrm{T}_{\text {tabel, }}$, dan nilai signifikan yang lebih kecil dari pada alpha 5\%, maka kesimpulan yang bisa diambil adalah menolak Ho yang berarti signifikan secara statistik. Untuk variabel harga (X1) terlihat bahwa $\mathrm{T}_{\text {hitung }}$ lebih besar dari pada $\mathrm{T}_{\text {tabel }}$ dan nilai signifikan lebih kecil dari pada alpha, maka kesimpulan yang bisa diambil adalah menolak Ho yang berarti signifikan 
secara statistik. Untuk variabel biaya Promosi (X2) terlihat bahwa $\mathrm{T}_{\text {hitung }}$ lebih besar dari pada $\mathrm{T}_{\text {tabel }}$ dan nilai signifikan lebih kecil dari pada alpha, maka kesimpulan yang bisa diambil adalah menolak Ho yang berarti signifikan secara statistik dan untuk variabel biaya distribusi (X3) terlihat bahwa Thitung lebih kecil dari pada Ttabel dan nilai signifikan lebih kecil dari pada alpha, maka kesimpulan yang bisa diambil adalah menerima Ho yang berarti tidak signifikan secara statistik. Persamaan regresi berganda untuk prediksi penjualan adalah:

$$
\begin{aligned}
& Y=3,574+5,547 X i+12,498 X 2 \\
& +-7,955 X 3 \\
& \text { Dimana : } \\
& Y \text { adalah penjualan } \\
& X_{1} \text { adalah Harga } \\
& X_{2} \text { adalah Biaya Promosi } \\
& X_{3} \text { adalah Biaya Distribusi }
\end{aligned}
$$

Dari tabel model summary terlihat bahwa koefisien korelasi berganda antara Harga, Biaya Promosi dan Biaya Distribusi terhadap Penjualan adalah sebesar KESIMPULAN DAN SARAN Kesimpulan

Berdasarkan hasil anal ${ }^{\mathrm{y}}$ sis dan pembahasan, maka dapat ditarik beberapa kesimpulan sebagai berikut:

a. Bauran pemasaran adalah bagian dari manajemen pemasaran yang harus diterapkan oleh setiap perusahaan, di iklans merupakan salah sate konsep yang sangat penting untuk diperhatikan terutama dalam hubungannya dengan proses pengambilan keputusan di bidang pemasaran. Faktor-faktor tersebut sangat mempengaruhi
0,999 (R). Nilai koefisien determinasi dan persamaan regresi adalah sebesar 0,997 $\left(\mathrm{R}^{2}\right)$ dengan nilai koefisien determinasi yang disesuaikan yang disesuaikan sebesar 0,994 . Karena persamaan regresi menggunakan lebih dari satu variabel, maka koefisien determinasi yang balk untuk digunakan dalam menjelaskan persamaan ini adalah koefisien determinasi yang disesuaikan. Dari tabel tersebut, nilai koefisien determinasi yang disesuaikan adalah sebesar 0,994 yang berarti sebanyak 99,4\% variabel atau perubahan dalam penjualan bisa dijelaskan oleh perubahan atau variasi dari variabel harga, biaya promosi dan biaya distribusi.

Dengan demikian hipotesis yang dikemukakan dalam penelitian diterima, artinya terdapat pengaruh yang positif dan signifikan antara bauran pemasaran terhadap penjualan saos samba) Indofood pada PT. Nestle Indofood Citarasa Indonesia.

hasil penjualan pada PT. Nestle Indofood Citarasa Indonesia di Makassar dari tahun ke tahun.

b. Dari hasil analisis regresi linier berganda antara produk, biaya promosi, biaya distribusi terhadap hasil penjualan dari tahun 2009 sampai tahun 2015 diperoleh persamaan sebagai berikut:

$$
\begin{aligned}
& \mathrm{Y}=\mathbf{3 , 5 7 4}+\mathbf{5 , 5 4 7} \mathrm{X}_{1}+\mathbf{1 2 , 4 9 8} \\
& \mathrm{X} 2+-\mathbf{7 , 9 5 5} \text { X3 }
\end{aligned}
$$

c. Hasil perhitungan regresi berganda diperoleh bahwa terdapat hubungan yang signifikan antara marketing mix terhadap volume penjualan saos 
sambal Indofood. Hasil tersebut dibuktikan dengan nilai koefiisen korelasi dan koefisien determinasi yang dilanjutkan dengan uji-t dan uji-f. Berdasarkan hasil perhitungan diperoleh koefisien korelasi sebesar 0,999 . Artinya terdapat hubungan yang sangat kuat dan positif antara marketing mix dengan volume penjualan saos sambal Indofood. Sedangkan nilai koefisien determinasi $\left(\mathrm{R}^{2}\right)$ sebesar 0,997 artinya 99,7\% volume penjualan saos sambal Indofood mampu dijelaskan oleh harga, promosi dan saluran distribusi, sedangkan sisanya $1 \%$ dijelaskan oleh faktor atau variabel lain yang tidak memuaskan dalam model (dalam hal ini variabel produk yang merupakan variabel yang tidak diteliti).

d. Hasil pengujuian balk uji-t maupun uji-F pada taraf nyata a $=0.05$ diperoleh nilai $\mathrm{t}$ - hitung $>$ $\mathrm{t}$-tabel untuk variabel promosi dan variabel harga serta saluran distribusi diperoleh nilai $t-$ hitung < t-tabel. Sedangkan uji$\mathrm{F}$ menunjukkan bahwa nilai $\mathrm{F}$ hitung > F-tabel pada masingmasing $a=0,05(351,340>9,28)$.

\section{DAFTAR PUSTAKA}

Arif Tiro Muhammad, 2004, Analisis Korelasi dan Regresi, Cetakan Ketiga, Edisi Revisi, Universitas Negeri Makassar.

Anoraga Pandji, 2000. Manajemen

Bisnis. Cetakan Kedua, PT.

\section{Saran}

Berdasarkan pada kesimpulan penelitian, maka berikut ini penulis akan ajukan beberapa saran yang berguna bagi perusahaan.

e. PT. Nestle Indofood Citarasa Indonesia di Makassar hendaknya mempertahankan kebijakan bauran pemasaran yang telah diterapkan atau dijalankan oleh perusahaan lebih dikembangkan mengingat tingkat persaingan yang semakin ketat pada tahun-tahun yang akan datang.

f. Hendaknya pimpinan perusahaan kiranya lebih berhati-hati di dalam mengeluarkan harga penjualan sebab dapat mengakibatkad penurunan penjualan di mass yang akan datang.

g. Disarankan kepada manajemen perusahaan bahwa dalam rangka meningkatkan volume penjualan pada PT. Nestle Indofood Citarasa Indonesia di Makassar untuk masa yang akan datang agar dapat memaksimalkan kebijakan dibidang promosi, sehingga volume penjualan khususnya produk saos sambal Indofood meningkat.

Rineka Cipta. Jakarta.

Buchari Alma, 2002, Manajemen

Pemasaran Dan Pemasaran

Jasa, Cetakan Kelima, Edisi

Revisi, Alfabeta, Bandung

Gitosudarmo, Indriyo dan Agus

Mulyana. 2000. Prinsip

Dasar

Manajemen. Edisi ketiga, 
Cetakan Keempat, BPFE. Yogyakarta.

Kotler, Philip. 2002. Terjemahan oleh Hendra Teguh, Ronny A. Rusli, Benyamin Molan. Manajemen Pemasaran, Edisi Milenium, jilid 2. PT Incleks- Jakarta.

2004 Terjemahan oleh Hendra Teguh, Ronny A. Rusli, Benyamin Molan. Manajemen Pemasaran, $\quad$ Edisi Milenium, jilid 1. PT Indeks. Jakarta.

Iklanullang, M.2000. Pengantar Bisnis. Cetakan Pertama, Gajah Mada. University Press. Yogyakarta.

Radio Sunu, 2001. Manajemen Pemasaran: Suatu pendekatan Analisis, Edis ${ }^{i}$ Kedua Cetakan Kelima, BPFE. Yogyakarta.

Render, Barry dan Jay Heizer. 2001. Prinsip-Prinsip Manajemen Operasi (Alih Bahasa : Krasnohadi Ariyoto). Salemba Empat. Jakarta:

Soprihanto, John dan Murti Sumarni. 2003. Pengantar Bisnis. Liberty. Yogyakarta.

Sudjana, 1996, Metode Statistika. Edisi Kedelapan, Tarsito. Bandung.

Sumarni, Murti dan John Soeprihanto. 2003. Pengantar Bisnis (DasarDasar Ekonomi Perusahaan), Edisi Kelima, Cetakan Keempat, Liberty, Yogyakarta.

Sunarto, 2004. Prinsip-Prinsip Pemasaran. Amus . Yogyakarta. Supranto, J dan Nandan Limakrisna. 2007. Perilaku
Konsumen dan Strategi

Pemasaran. Mitra Wacana Media. Jakarta. Wangsi, M. M., \& Rawi, R. D. P. (2018). Perlindungan Konsumen Dalam Pelabelan Produk Menurut Ekonomi Islam. Sentralisasi, 7(1), 19. 